Research Article

\title{
The Role of Deleted in Colorectal Cancer (Dcc) and P53 Mrna Expression In Young Colorectal Cancer Patients
}

\author{
Budhi IB, Metria IB, Hanafi B, Herri SS, Effendi JS \\ Surgery Department, Medical Faculty, Sebelas Maret University \\ Medical Faculty, Sebelas Maret University \\ Digestive Surgery Division, Padjadjaran University \\ Pharmacology Department, Padjadjaran University \\ Obstetry Gynecology Department, Padjadjaran University
}

\begin{abstract}
Background : The incidence of colorectal malignancies at a young age, and the absence of sufficient data to explain about it, including in terms of gene mutations that play a role. The research will be done here is to determine whether changes in mRNA expression of genes DCC ( deleted in colorectal cancer ) and p53 play a role in colorectal malignancy is less than 40 years of age. Researchers also will perform immunohistochemistry to look at protein expression of the gene and protein expression was evaluated whether these correlated with mRNA expression.

Methods : This study is an observational analytic cross sectional design, carried out in the Laboratory of Biomedical Faculty of Medicine Sebelas Maret University from June 2013 to March 2014. Subjects were 30 patients with stage III colorectal adenocarcinoma, with details of the 15 subjects for each group. Subjects taken by consecutive sampling. Immunohistochemical examination of paraffin block preparation and reverse transcriptase - polymerase chain reaction (RT - PCR) of tumor tissue samples for evaluation of the presence of the protein and mRNA expression of DCC and p53 genes .
\end{abstract}

Statistical analysis using the chi-square test and Phi correlation.

Results : the 4 subjects in the age group $\leq 40$ years was not accompanied by DCC protein expression while in the age group $>40$ years of protein expression obtained in all preparations. Expression of p53 protein more available in the age group > 40 years ( 3 subjects ), in the age group $\leq 40$ years is only found in 1 subject. Examination results of RT-PCR to assess the mRNA expression results are consistent with the results of immunohistochemistry. Eleven subjects from the age group $\leq 40$ years obtained DCC mRNA expression, whereas p53 mRNA expression was found in 12 subjects. From statistical analysis using the chi-square test and Phi correlation, we found significant association between protein and mRNA expression of DCC with colorectal cancer aged $\leq \mathbf{4 0}$ years. Correlation of test results, obtained significant correlation between mRNA expression of DCC with colorectal cancer aged $\leq 40$ years and the results of protein expression were significantly correlated with mRNA expression of DCC and p53 genes.

Conclusion : the expression of 553 protein and mRNA did not play a role in colorectal cancer $\leq 40$ years of age. Protein expression was positively correlated with mRNA expression .

Keywords : colorectal cancer, DCC protein , protein p53, DCC mRNA , p53 mRNA

\section{Introduction}

Colorectal carcinoma is the most common malignancy of the digestive tract. In the United States, more than 145,000 new cases diagnosed and 55,000 patients died each year. Colorectal carcinoma is the second cause of death after breast cancer in the United States. Comparisons between men and women are more or less the same, and the incidence has not changed over the past 20 years.[1,2]

Colorectal cancer is a genetic disorder in which $70 \%$ of cases are sporadic. There are several genes that play a role in the occurrence of colorectal cancer, but its role in preventing the progression is the DCC gene and p53.[3-8]
One factor that has a role in the process of protein expression of a gene is mRNA, whose role as a transcription factor. From the research that has been reported by ASCO in 2010, the mRNA expression of tumor suppressor genes can be used as one investigation for screening cases of malignancy colorectal, which is expected to reduce the number of false positives and false negatives of the examination at the level of protein expression.[5,7,9]

The expression of these genes is indispensable in maintaining adhesion between cells, communication between cells, and as a control of apoptosis. To see whether the gene is still able to 
function as a tumor suppressor gene, we can examine mRNA expression level and the more modest examination of protein expression.[10-14] Examination of protein expression is said to still have a number of false positives and may not necessarily reflect whether a mutation or not.[12,14] With the increasing incidence of colorectal malignancy at a young age, and lack of sufficient data to explain about it, including in terms of mutations in genes that play a role, research will be done here is to determine whether changes in mRNA expression DCC gene and p53 plays a role in colorectal malignancy less than 40 years old.

\section{Methods}

The paraffin block specimens were used for imunohistochemist examination.

By using RT-PCR technique, we examined the DCC and p53 mRNA expression from fresh tumor tissues of colon and rectal cancer patients. RNA isolation was done, following by qualitative RNA concentration examination and then we did realtime reverse transcriptase-PCR.

The tumor location was also evaluated in this study.

Data were analyzed using the Chi-square test, and the correlation was evaluated using Coefficient Contingentie

\section{Results}

From the results of the qRT-PCR to assess the DCC gene mRNA expression, obtained a mean increased expression in the age group less than 40 years old of 0.078 , while the increase in mRNA expression obtained DCC higher in the age group more than 40 years old.

\section{Table 1 Subject Characteristic}

\begin{tabular}{|c|c|c|c|c|c|}
\hline & & \multicolumn{2}{|c|}{ Age } & \multirow{2}{*}{ Total } & \multirow{2}{*}{$\mathbf{p}$} \\
\hline & & $\leq 40$ y.o & $>40$ y.o & & \\
\hline \multicolumn{6}{|l|}{ Sex } \\
\hline & Male & 6 & 11 & 17 & \multirow{2}{*}{0.065} \\
\hline & Female & 9 & 4 & 13 & \\
\hline \multicolumn{6}{|l|}{ Location } \\
\hline & Rectum & 9 & 10 & 19 & \multirow{4}{*}{0.693} \\
\hline & $\begin{array}{l}\text { Right } \\
\text { Colon }\end{array}$ & 3 & 2 & 5 & \\
\hline & $\begin{array}{l}\text { Sigmoid } \\
\text { Colon }\end{array}$ & 2 & 3 & 5 & \\
\hline & $\begin{array}{l}\text { Transverse } \\
\text { Colon }\end{array}$ & 1 & 0 & 1 & \\
\hline
\end{tabular}

In this study, we found rectum as the commonest site of colorectal cancer in both group of age although there was no correlation between age and sex or location.
Table 2 Age and mRNA Expression Correlation

\begin{tabular}{|c|c|c|c|c|}
\hline \multirow{2}{*}{$\begin{array}{c}\text { mRNA } \\
\text { Expression }\end{array}$} & \multicolumn{2}{|c|}{ Age } & \multirow{2}{*}{$\mathbf{p}^{*)}$} & \multirow{2}{*}{$\underset{\left.{ }_{*}\right)}{\text { C }}$} \\
\hline & $\leq 40$ y.o & $>40$ y.o & & \\
\hline \multicolumn{5}{|l|}{$D C C$} \\
\hline & 0.078 & 0.295 & 0.674 & 0.000 \\
\hline \multicolumn{5}{|l|}{ p53 } \\
\hline & 0.790 & 0.316 & 0.650 & 0000 \\
\hline
\end{tabular}

Table 2 shows the age group of less than 40 years old, an increase in the expression of mutant p53 mRNA in the age group less than40 years old was 0.790 , higher than in the age group more than 40 years old.

To assess the relationship between age and DCC mRNA expression Chi-Square test, Pearson chi-square value was 0.674 ( $p>0.05$ ). Based on this statistical test, no significant correlation between age and DCC gene mRNA expression.

Pearson chi-square values obtained 0.650 ( $p>0.05)$. There were no significant correlation between age and the expression of mutant p53 mRNA.

Table 3 DCC Protein and mRNA DCC Correlation

\begin{tabular}{cccc}
\hline $\begin{array}{c}\text { DCC } \\
\text { Expression }\end{array}$ & $\begin{array}{c}\text { mRNA } \\
\text { DCC }\end{array}$ & $\mathbf{p}^{*)}$ & $\begin{array}{c}\mathbf{C} \\
\left.\text { Correlation }^{* *}\right)\end{array}$ \\
\hline IHC DCC (-) & 0.077 & 0.000 & 0.638 \\
IHC DCC (+) & 0.186 & &
\end{tabular}

${ }^{*}: \mathrm{p}$ : result of the Chi-Square test

*): C : Coefficient Contingentie

Table 4 p53 Protein and mRNA p53 Correlation

\begin{tabular}{|c|c|c|c|}
\hline $\begin{array}{c}\text { p53 } \\
\text { Expression }\end{array}$ & $\begin{array}{c}\text { mRNA p53 } \\
\text { mutant }\end{array}$ & $\mathbf{p}^{*)}$ & C Correlation $^{* *}$ \\
\hline \multirow[t]{2}{*}{ IHC p53 (-) } & 0.498 & & \\
\hline & & 0.006 & 0.507 \\
\hline IHC p53 (+) & 0.645 & & \\
\hline
\end{tabular}

From table 3 and table 4, we found correlation between protein and mRNA expression from DCC and p53 gene $(\mathrm{p}<$ $0.005)$.

\section{Discussions}

This study was conducted in 30 cases of colorectal malignancy compared between the age group less and more than 40 years old. Comparison assessed protein and mRNA expression of two tumor suppressor genes that play a role in 
the development of colorectal malignancy were DCC and p53 genes.

Is associated with the expression of protein and mRNA of the gene $\mathrm{p} 53$, the age factor does not provide a meaningful relationship, the accumulation of p53 expression at both protein and mRNA more found in the age group over 40 years, but not statistically significant association ( $p>0,05)$. Meanwhile, when evaluated from the location factor for colorectal malignancies, are not obtained relationship with both protein and mRNA expression of two tumor suppressor genes such, it is consistent with studies have reported that the expression of protein and mRNA was not affected by the location of colorectal malignancy. However, the mechanism associated with the development of this malignancy is through LOH (loss of heterozigosity), there is a tendency to malignancy in the right colon, while the mechanisms of mismatch repair genes (MMR) tend to occur in the left colon with a less favorable prognosis.[11-12]

Additional information on the pathogenesis of colorectal malignancy of this research is the role of genes DCC (deleted in colorectal cancer) on the occurrence of colorectal malignancy in the age group $\leq 40$ years. Previous research ever reported by Shibata, stated that the presence or absence of the protein expression of the DCC gene serves as a prognostic factor, in which case that is not accompanied by protein expression DCC gene has a worse prognosis, also described in the study, in the case of stage II colorectal malignancy that is not accompanied the DCC protein expression has the same prognosis with stage III colorectal malignancy.[12-15]

Other research data stating the role of this gene expression in predicting response to adjuvant chemotherapy, and otherwise also the role of thymidilate synthase as a predictor factor.[16]

Examination at the protein level by immunohistochemistry technique to see whether or not the protein expression of the gene have a number of false positives and negatives when compared to examination in the mRNA level by RT-PCR examination. In this study, both immunohistochemical examination or RT-PCR that has been done to give consistent results, it can be considered to carry out checks on the protein level when another inspection has not been possible to do.

Gen DCC (deleted in colorectal cancer) is a tumor suppressor gene located on the long arm of chromosome 18 (18q), plays a role in suppressing the progression by maintaining adhesion between cells remain good, studies that have been reported to express the gene mutation is present in approximately $70 \%$ of cases of colorectal malignancy regardless of age.[17-19] In the present study, the age factor is evaluated to see if there is a different expression patterns among younger age groups in the age group over 40 years. Good views of the expression of protein and mRNA, the age group of less than 40 years old tend not to give expression, it is one of the factors increasing the incidence of malignancy Colorectal at a young age and patients present in advanced stages with a progression that is higher than the age group old. Other genes that have the same location with the DCC gene is

Smad 4.[19]

P53 gene located on the short arm of chromosome 17 (17P) is a tumor suppressor gene that plays a role in controlling apoptosis, several studies were performed to evaluate the role of this gene as a prognostic factor but not yet provide meaningful results. Mutations of these genes can be found in approximately $50 \%$ of cases. Examination of both immunohistochemistry and RT-PCR were performed to see his expression to assess the accumulation of mutant p53 contained in the cell nucleus.(20) This study can not provide meaningful information on the role of p53 expression in colorectal malignancy at age $\leq 40$ years.

In the process of colorectal malignancy (adenoma-casinoma sequences) involving multiple gene mutations in each stage of development, from early to late adenoma adenoma and metastasis. The interaction between these genes could be evaluated, the research that has been done assessing the interactions between expression of K-ras, APC and p53. The results obtained are meaningful only on the interaction between p53 and APC. While the interaction between p53 and K-ras did not provide important role.[21-25] In this study, are associated with colorectal malignancy that occurs at a younger age (less than 40 years), not found a significant interaction between DCC and p53 expression. Given the age factor, the protein and mRNA expression of DCC is to play a role.

In clinical practice, examination of both immunohistochemistry and RT-PCR in the case of colorectal malignancy is not routinely performed, its use is still within the scope of clinical research. With the increasing number of reports research on the role of the expression of these genes in malignancy colorectal well as one of the factors prognosis and prediction of progression and response to chemotherapies, including the results of this study provide additional information on the malignancy of colorectal mainly in the age group $\leq 40$ years, it could be possible the inspections began as a routine examination in clinical practice treatment of colorectal malignancy.

To test the hypothesis proposed in this study, performed statistical analysis with SPSS 19 used chi square analysis. Protein expression and mRNA of the DCC gene and p53 is mostly found in the age group $>40$ years, however, only the expression of protein and mRNA DCC who have a role in relation to the age factor $(p<0.05)$. The results of this study also showed that the protein expression of both genes were positively correlated with the results of the expression mRNAnya.

Although the studies were conducted in the same stadium, not all cases have the same expression pattern, especially in the age group $\leq 40$ years, $27 \%$ are not accompanied by the expression of protein and mRNA DCC.

Anchored by the ferocity of the other organs of the digestive tract, there is a decrease in mRNA expression in gastric malignancy DCC, not only play a role in the emergence of malignancy itself, but also play a role in the occurrence of 
distant metastases to the liver.[26]

This study concludes that the role of the protein and mRNA expression of the p53 gene in colorectal malignancy young age. Research reported by Shin IY in 2014, said the role of p53 expression to progression, including the spread to lymph nodes and distant metastases. Reported also the role of p53 against colorectal cancer stage.[27]

p53 gene is said to be the guardian of the genome, protein p53 plays a role evaluate and recognize the damage of the cell and its function by inhibiting the cell cycle so that it is possible to perform DNA repair or, if not possible, will induce apoptosis.

Regulation of p53 gene can occur before the stage of translation, involving increased expression of the p53 gene as well as the stabilization of p53 mRNA expression. P53 gene has the ability to stimulate transcription itself, induced by internal promoter in the MDM2 gene, the gene products identified oncoprotein MDM2 acts as a negative regulator of the p53 gene. By binding to the gene p53, MDM2, inhibiting the ability to activate gene transcription process 53 . So that in cases where a mutation in the p53 gene, accompanied by the absence of negative feedback resulting in overexpression of p53 gene mRNA.

Other research reported by $\mathrm{Xu} \mathrm{W}$, according to the results of this study, it was stated that p53 expression was not associated with age, gender and location of colorectal cancer.[28]

From the standpoint of psychoneuroimmunology, greater volumes of the DCC protein expression (tumor suppressor gene) in the older group is made possible because the older people, stressor is lower, so that protein synthesis is not inhibited by a factor of cortisol. The release of cortisol is triggered by the presence of individual stress factors.

Akkiprik M, conducted a study in stage I and II colorectal cancer, stated that in addition to genetic testing, immunohistochemical examination can also be performed to assess the expression of the protein p53 abnormalities. Overexpression of p53 gene is more common in the left colon, so it is possible pathogenesis that is different from what happened in the colon right. At this stage, the expression of the p53 gene does not have a meaningful relationship with life expectancy.[29]

In the colorectal cancer group were sporadic, Xiu-ying reported the role of alteration on chromosome 17P (p53 gene locations) against metastasis, progression and prognosis.[30]

In this study, the protein and mRNA expression of mutant p53 genes more patients with colorectal cancer was found in the age group $>40$ years, this is not consistent with the hypothesis put forward that the expression of mutant p53 protein and mRNA more found in the age group $\leq 40$ years for in the younger age group, mutations occur early in the development stage. It is powered for the p53 gene are not spresifik in colorectal cancer, in some malignancies in other organs, the p53 gene is also mutated.

In the process of cancer, not only played by a mutation of the tumor suppressor gene, there are some other factors that come into play such defects or mutations in proto-oncogenes, increased apoptosis inhibitor gene activation and decreased activation of apoptosis stimulating genes. Suppresor genes inhibit tumor growth and inducing cell differentiation, so that the mutation of the gene will result in the protein becoming inactive and loss of inhibition of the progression of cancer development.

Colorectal cancer were found in younger age groups, in this study were less than 40 years old age, is a multi-factor process, factors remain a gene mutation in sporadic group. In addition to genetic factors, which play an important role in the process of colorectal cancer are environmental factors, food consumption habits low in fiber and high in animal protein is play a role in the process.

The presence of gene mutations that occur early in the development stage colorectal cancer patients younger age, followed by accumulation of mutations that exist primarily in tumor suppressor genes result in higher progression compared to patients with older age. Colorectal cancer treatment protocol that is used when no one has to use and distinguish the age factor in the delivery of adjuvant therapy. This is what makes a basic consideration for adjuvant chemotherapy in patients with colorectal cancer a young age which no longer obtain protein and mRNA expression of DCC gene. So expect after getting the handling of surgery and adjuvant therapy, we will be able to reduce the recurrence rate and may increase the rate of disease free survival.

\section{References}

1. Kelli BM. 2009. Colon, rectum and anus. In Schwartz's principles of surgery. $8^{\text {th }}$ Edition, 1060-115.

2. Grady WM. 2008. Colorectal cancer: molecular biology and genetics. In Principles and practise of gastrointestinal oncology. 2nd Edition, 539-550.

3. McDermott U, Longley DB, Galligan L, Allen W, Wilson T, Johnston PG. 2009. Effect of p53 status and STAT1 on chemotherapy-induced, fas-mediated apoptosis in colorectal cancer. Tersedia dari: www.aacrjournals.org

4. Aschele C, Debernardis D, Lonardi S. 2009. Deleted in colon cancer protein expression in colorectal cancer metastases: a major predictor of survival in patients with unresectable metastatic disease receiving palliative fluorouracil-based chemotherapy. J Clin Oncology. (May 2009).

5. Mehlen P, Fearon ER. 2009. Role of the dependence receptor DCC in colorectal cancer pathogenesis. J Clin Oncology. (Oct 2009).

6. Kandioler D, Pilat N, Kappel S, Gruenberger T, Laengle F, Mittlboeck M, et al. 2009.

A prospective study of the interaction between p53 genotype and overall survival in patients with colorectal cancer liver metastases with and without neoadjuvant therapy (oxaliplatin and capecitabine/5-FU): A p53 reseach group study. J Clin 
Oncology. (May 2009).

7. Russo A, Bazan V, Iacopetta B, Kerr D, Sousi T, Gebbia N. 2009. The TP53 colorectal cancer international collaborative study on the prognostic and predictive significance of $p 53$ mutation: influence of tumor site, type of mutation, and adjuvant treatment. J Clin Oncology. (Nov 2009).

8. Locker GY, Hamilton S, Harris J, Jessup JM, Kemeny N, Mcdonalds JS, et al. 2006. ASCO 2006 update of recommendations for the use of tumor markers in Gastrointestinal cancer. J Clin Oncology. (Oct 2006).

9. Popat S, Chen Z, Zhao D, Pan H, Hearle N, Chandler I, et al. 2009. A prospective, blinded analysis of thymidylate synthase and p53 expression as prognostic markers in the adjuvant treatment of colorectal cancer. Ann Oncology. (Nov 2009).

10. Mollevi DG, Serrano T, Ginesta MM, Valls J, Torras J, Jaurrieta E, et al. 2009. Mutations in TP53 are a prognostic factor in colorectal hepatic metastases undergoing surgical resection. www.carcin.oxfordjournals.org

11. Folprecht G, Seymour MT, Saltz L, Douillard JY, Hecker H, Stephens RJ, et al. 2009. Irinotecan/fluorouracil combination in first-line therapy of older and younger patients with metastatic colorectal cancer: combined analysis of 2,691 patients in randomized controlled trials. J Clin oncol. (Mar 2009).

12. Hill DA, Furman WL, Billups CA, Riedley SE, Cain AM, Rao BN, et al. 2007. Colorectal carcinoma in childhood and adolescence: A clinicopathologic review. J Clin oncol. (Dec 2007).

13. Liang H, Wang XN, Wang BG, Pan Yuan, Liu Ning, Wang DC, et al. 2006. Prognostic factors of young patients with colon cancer after surgery. World J Gastroenterology. (Oct 2006).

14. Boardman L A, Chiu Y S, Petrauskene O, Wieczorek L, Moore D H, Ballman K V, et al. 2010. A novel, non invasive, mRNA gene expression colon cancer screening methodology. J Clin Oncol. (Jan 2010)

15. Hill D A, Furman W L, Billups C A, Riedley S E, Cain A $\mathrm{M}$, Rao B N, et al. Colorectal carcinoma in childhood and adolescence: a clinicopathologic review. J Clin Oncol. 2007; 25: 5808-814.

16. Pritchard CC, Grady WM. 2011. Colorectal cancer molecular biology moves into clinical practice. Gut. (Jan 2011).

17. Sheffer M, Bacolod MD, Zuk O, Giardina SF, Pincas H, Barany F, et al. 2009. Association of survival and disease progression with chromosomal instability: A genomic exploration of colorectal cancer. Proc Natl Acad Sci. (Apr 2009), 7131-6.
18. Ueda Y, Yasuda K, Inomata M, Shiraishi N, Yokoyama S, Kitano S. 2013. Biological predictors of survival in stage II colorectal cancer. Mol Clin Oncol. (Jul 2013), 643-8.

19. Bacolod MD, Barany F. 2011. Molecular profiling of colon tumors: the search for clinically relevant biomarkers of progression, prognosis, therapeutics, and predisposition. Ann Surg Oncol. (Dec 2011), 3694-700.

20. Liang JT, Huang KC, Cheng AL, Jeng YM, Wu MS, Wang SM. 2003. Clinicopathological and molecular biological features of colorectal cancer in patients less than 40 years of age. Br J Surg. (Feb 2003), 205-14.

21. Popat S, Zhao D, Chen Z, Pan H, Shao Y, Chandler I, et al. 2007. Relationship between chromosome 18q status and colorectal cancer prognosis: a prospective, blinded analysis of 280 patients. Anticancer Res. (Feb 2007), 627-33.

22. Tsanou E, Peschos D, Batistatou A, Charalabopoulos A, Charalabopoulos K. 2008. The E-cadherin adhesion molecule and colorectal cancer. A global literature approach. Anticancer Res. ～(Dec 2008), 3815-26.

23. Chiang J-M, Wu Chou Y-H, Ma S-C, Chen J-R. 2004 . Influence of age on adenomatous polyposis coli and p53 mutation frequency in sporadic colorectal cancer-rarity of co-occurrence of mutations in APC, K-ras, and p53 genes. Virchows Arch Int J Pathol. (Nov 2004), 465-71.

24. Smith G, Carey FA, Beattie J, Wilkie MJV, Lightfoot TJ, Coxhead J, et al. 2002. Mutations in APC, Kirsten-ras, and p53--alternative genetic pathways to colorectal cancer. Proc Natl Acad Sci U S A. (Jul 2002), 9433-8.

25. Pan Z-Z, Wan D-S, Chen G, Li L-R, Lu Z-H, Huang B-J. 2004. Co-mutation of p53, K-ras genes and accumulation of p53 protein and its correlation to clinicopathological features in rectal cancer. World J Gastroenterol. (Dec 2004), 3688-90.

26. Yoshida Y, Itoh F, Endo T, Hinoda Y, Imai K. 2008. Decreased DCC mRNA expression in human gastric cancers is clinicopathologically significant. Int $\mathbf{J}$ Cancer $\mathbf{J}$ Int Cancer. (Dec 2008), 634-9.

27. Shin IY, Sung NY, Lee YS, Kwon TS, Si Y, Lee YS, et al. 2014. The Expression of multiple proteins as prognostic factors in colorectal cancer: Cathepsin D, p53, COX-2, Epidermal Growth Factor Receptor, C-erbB-2, and Ki-67. Gut Liver. (Jan2014), 13-23.

28. Xu W, Cheng Y, Shen XF. 2012. A study on the mutation of p53 and K-ras gene in colorectal adenomas and colorectal carcinomas. (Nov 2012), 821-6

29. Akkiprik M, Ataizi-Celikel C, Ataizi-Celikel C, Düşünceli F, Sönmez O, Gulluoglu BM, et al. 2007. Clinical significance of p53, K-ras and DCC gene alterations in the stage I-II colorectal cancers. J Gastrointest Liver Dis. (Mar 2007), 11-7. 
30. Xiao X-Y, Zhou X-Y, Yan G, Sun M-H, Du X. 2007. Chromosomal alteration in Chinese sporadic colorectal carcinomas detected by comparative genomic hybridization. Diagn Mol Pathol Am J Surg Pathol Part B. (Jun 2007), 96-103. 